\title{
INVESTIGATION STUDIES INVOLVING WEAR-RESISTANT ALD/PVD HYBRID COATINGS ON SINTERED TOOL SUBSTRATES
}

\author{
PREISKAVE OBRABNE ODPORNOSTI HIBRIDNEGA NANOSA \\ ALD/PVD NA SINTRANEM ORODJU
}

\author{
Marcin Staszuk, Daniel Pakuła, Tomasz Tański \\ Silesian University of Technology, Institute of Engineering Materials and Biomaterials, Konarskiego Street 18A, 44-100 Gliwice, Poland \\ marcin.staszuk@polsl.pl
}

Prejem rokopisa - received: 2015-07-22; sprejem za objavo - accepted for publication: 2015-10-13

doi:10.17222/mit.2015.236

This paper is an important research contribution to the development of PVD coatings, in particular, on ceramic substrates, which, due to their dielectric properties, are difficult materials to coat using this technique. In order to satisfy the desired expectations relating to the PVD coatings, one of the basic properties must be provided for, the adherence to the substrate. The main aim of this research is to investigate the structure and mechanical properties of the coatings deposited in a hybrid process, comprising the atomic-layer deposition (ALD) and cathodic-arc evaporation (CAE-PVD) on sintered carbides and multipoint ceramic cutting tools. The concept of this research study involves an execution and investigation of ALD + PVD hybrid coatings on sintered carbides and a sialon-ceramic substrate, and defining the influence of the ALD interlayer on the adherence of the investigated coatings. The critical load $L_{\mathrm{c}}$, which is the adhesion measure of coats, was determined with the scratch-test method and a tribological test made with a pin-on-disk tester. Observations of the surface topography and wear mechanism were performed using a scanning electron microscope and atomic-force microscopy. The investigation studies showed that an ALD layer considerably improves the adherence of the PVD layer to the tool-ceramic substrate. The research of the coatings on sintered-carbide substrates showed that the adherence of the PVD coating to the substrate deteriorates in the case of applying an ALD interlayer.

Keywords: PVD, ALD, hybrid coatings, tool ceramics, sintered carbides

Članek je pomemben raziskovalni prispevek k razvoju PVD nanosov, še posebno na keramični podlagi, ki je zaradi dielektričnih lastnosti zahteven material za nanašanje s to tehniko. Da bi zadovoljili pričakovanja na delu s PVD nanosom, je oprijemljivost na podlago osnovna lastnost, na katero je potrebno biti pozoren. Glavni namen raziskave je preiskati strukturo in mehanske lastnosti nanosa, nanešenega s hibridnim postopkom, ki obsega nanos atomskih plasti (ALD) in katodno izparevanje v obloku (CAE-PVD) na sintrane karbide in večtočkovno keramično rezilno orodje. Koncept te raziskave vključuje izvedbo in preiskavo hibridnega nanosa ALD + PVD na podlago iz sintranih karbidov in sialon keramike ter določitev vpliva vmesne plasti ALD na oprijemljivost preiskovanih nanosov. Kritična obremenitev $L_{\mathrm{c}}$, ki je merilo oprijemljivosti nanosov, je bilo določeno s preizkusom razenja in $s$ tribološkim preizkusom trn na plošči. S pomočjo vrstičnega elektronskega mikroskopa in mikroskopa na atomsko silo je bilo izvedeno opazovanje topografije površine in mehanizma obrabe. Izvedene preiskave kažejo, da ALD nanos močno izboljša oprijemljivost PVD nanosa na orodno keramiko. Pri nanosu na podlago iz sintranega karbida je raziskava pokazala, da je pri uporabi ALD vmesne plasti, oprijemljivost PVD nanosa slabša.

Ključne besede: PVD, ALD, hibridni nanosi, keramika za orodja, sintrani karbidi

\section{INTRODUCTION}

Sialon-tool ceramics are a group of tool materials combining the mechanical properties of silicon nitride $\mathrm{Si}_{3} \mathrm{~N}_{4}$ and the chemical properties of $\mathrm{Al}_{2} \mathrm{O}_{3}$. Ceramic sinters are fabricated with powder-metallurgy methods, but in contrast to sintered carbides, they do not contain a metallic binder. The use of tool ceramics as compared to sintered carbides is still considerably small but it is growing, also due to the application of thin wear-resistant layers PVD and CVD. ${ }^{1,2}$

Surface engineering technologies play a significant role in material engineering and are viewed as the fundamental scope of knowledge in this field of engineering. The research entities working in this field try to investigate and identify the phenomena taking place on the surfaces of the machined materials. In order to improve the operating properties of products, various surface-machining technologies are applied. ${ }^{2-6}$ The advantages arising from the application of PVD coatings on cutting tools such as a high microhardness and resistance to abrasion, a low friction coefficient of the tool covered with the coat, the resistance to oxidation or to the formation of build-up edges on the tool, combined with the possibility to machine materials without liquid cooling lubricants are important contributions advocating the development of this technological field. However, in order to improve the desired properties of PVD coatings, one of the basic properties must be taken care of, which is the adherence to the substrate. The coating of ceramic materials in PVD processes, including also tool ceramics, is difficult due to dielectric properties, since the inability of the substrate polarization during the coating 
process makes it difficult to obtain coatings with a good adherence to ceramic substrates. ${ }^{2,7-11}$

The fabrication technology of stratified coatings of the type "adhesive layer/PVD layer" using the multistage surface machining is one of the most modern methods to modify the properties of the surface layer and it consists, in a successive application, of two (or more) technologies of surface engineering. In terms of material effects, we obtain multilayer systems whereof one part is made up of an appropriately selected adhesive layer fabricated on the surface of the substrate, which protects the "proper" PVD layer against a loss of internal cohesion and an insufficient adhesion to the substrate. And on the other end of the system, we obtain a PVD coating which efficiently insulates the substrate, limiting the impact of the external harmful factors encountered in the operating process..$^{2,12}$

The coatings of the $(\mathrm{Ti}, \mathrm{Al}) \mathrm{N}$ type are isomorphic, with titanium nitride which is still widely applied. The presence of aluminum in the coatings of this type brings about the situation where the service-life temperature of these coatings exceeds $970 \mathrm{~K}$, and in such operating conditions of raised temperature, a layer of $\mathrm{Al}_{2} \mathrm{O}_{3}$ is formed on the surface, which forms a diffusive barrier for the atmospheric oxygen. ${ }^{13,14}$

Zinc oxide is a semiconductor characterized by a high energy gap (3.4 eV), high exciton binding energy (60 meV) and easy n-type doping. ${ }^{15,16}$ Zinc oxide, $\mathrm{ZnO}$, obtained with the use of the ALD technique on a sialonceramic substrate enables the polarization of this substrate during the technological process of PVD and, hence, the objective of this paper is to investigate the impact of the $\mathrm{ZnO}$ layer obtained with the use of the ALD technique on the adhesion of the hybrid coating ALD/PVD of the $\mathrm{ZnO} /(\mathrm{Ti}, \mathrm{Al}) \mathrm{N}$ type to the sialon substrate. For the sake of comparison, we also investigated the coatings on sintered carbide substrates.

\section{MATERIALS AND METHOD}

The research studies were carried out on multipoint cutting tools made of sintered carbides WC-Co and sialon-tool ceramics covered in the PVD and ALD/PVD processes. The tools were covered during the cathodicarc evaporation process CAE-PVD with the (Ti,Al)N coating type and in the ALD/PVD hybrid process using the $\mathrm{ZnO} /(\mathrm{Ti}, \mathrm{Al}) \mathrm{N}$ coating type.

The topography of the surfaces and wear mechanisms of the coatings was viewed with a Supra 35 scanning electron microscope from Zeiss. The secondary-electron (SE) detection was used to obtain the images of the tested samples, with an acceleration voltage of 5-20 kV.

The topography of the coatings was tested using a Park Systems XE-100 atomic-force microscope. The tests were carried out in the non-contact mode.

The adherence of the coatings to the substrate was assessed with a scratch test on a Revetest device from
CSEM. The method consists of moving a Rockwell C diamond indenter through the surface of a tested sample at a constant speed, with the applied force growing linearly. The ranges of the applied load were $0-100 \mathrm{~N}$ and $0-200 \mathrm{~N}$. The $L_{\mathrm{c}}$ critical load, at which the coating adhesion is lost, was determined according to the acoustic-emission value registered during the measurement and by observing the scratches formed during the scratch test.

The abrasive-wear-resistance tests and the wear-factor tests for the tested coatings were performed with the pin-on-plate method using a CSEM Tribometer (THT). A $6 \mathrm{~mm} \mathrm{Al}_{2} \mathrm{O}_{3}$ ball was used as the counter specimen. The tests were made at room temperature. The following test conditions were applied: a normal force of $F_{\mathrm{N}}=10 \mathrm{~N}$ and a movement speed of $v=0.1 \mathrm{~m} / \mathrm{s}$. The total distance of $1 \mathrm{~km}$ was set for all the tested specimens.

\section{DISCUSSION AND TEST RESULTS}

The value of critical load $L_{\mathrm{c}}$, being the adherence measure for the investigated coatings on sintered-carbide substrates or sialon-tool ceramic substrates, was determined using a scratch test (Figure 1). The research studies show that the ALD/PVD hybrid coat has a much
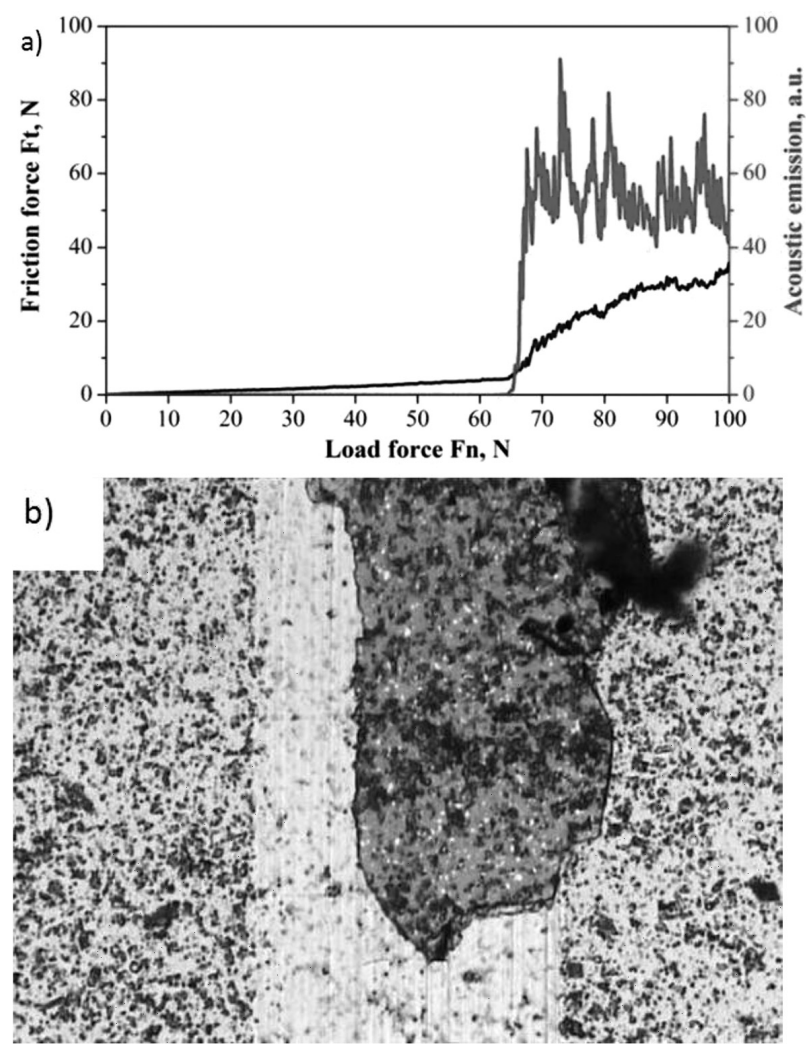

Figure 1: a) Acoustic emission (AE) and friction force $F_{\mathrm{t}}$ depending on load $F_{\mathrm{n}}$ for the $\mathrm{ZnO} /(\mathrm{Ti}, \mathrm{Al}) \mathrm{N}$ coating on sialon ceramics, b) scratch failure at $L_{\mathrm{c}}(\mathrm{opt})=65 \mathrm{~N}$, magnified $200 \times$

Slika 1: a) Akustična emisija (AE) in sila trenja $F_{\mathrm{t}} \mathrm{v}$ odvisnosti od obremenitve $F_{\text {n }}$ pri $\mathrm{ZnO} /(\mathrm{Ti}, \mathrm{Al}) \mathrm{N}$ nanosu na sialon keramiko, b) poškodba z razo pri $L_{\mathrm{c}}(\mathrm{opt})=65 \mathrm{~N}$, povečano $200 \times$ 
higher adherence to the sialon-ceramic substrate than the PVD coating without the adhesive layer (Table 1). A reverse situation takes place in the case of coatings on sintered-carbide substrates. Due to high adhesion of the PVD coating to the sintered-carbide substrate, the ALD layer causes a drop in the critical load from $109 \mathrm{~N}$ to $55 \mathrm{~N}$.

Table 1: Critical loads $L_{\mathrm{c}}$ of the investigated coatings

Tabela 1: Kritične obremenitve $L_{\mathrm{c}}$ preiskovanih nanosov

\begin{tabular}{|c|c|c|}
\hline \multirow{2}{*}{ Type of coating } & \multicolumn{2}{|c|}{ Critical load $L_{\mathrm{c}}, \mathrm{N}$} \\
\cline { 2 - 3 } & Sialon substrate & $\begin{array}{c}\text { Cemented-carbide } \\
\text { substrate }\end{array}$ \\
\hline (Ti,Al)N & 21 & 109 \\
\hline $\mathrm{ZrO} /(\mathrm{Ti}, \mathrm{Al}) \mathrm{N}$ & 64 & 55 \\
\hline
\end{tabular}

The damage done to the coats during the performed adhesion/scratch tests was identified on the basis of observations with the scanning electron microscope. The studies carried out show that it is the delamination, which is the principle mechanism of the coat damage on the sialon-ceramic substrate after the critical load $L_{\mathrm{c}}$ has been exceeded. In the case of the PVD coat, which is characterised by a low adherence to the ceramic substrate, a total delamination with vast chipping was identified. Furthermore, a low adherence of the PVD coat to the ceramic substrate indicates a considerable morphological non-homogeneity and, in particular, the presence of chippings found on the whole surface of the coat (except for the scratch area) (Figure 2). A low adherence of the coat to the substrate results in its unprompted chipping due to the internal strain of the coat. In the case of the $\mathrm{ZnO} /(\mathrm{Ti}, \mathrm{Al}) \mathrm{N}$ hybrid coat on the sialon substrate, delamination was identified on both sides of the sample (Figure 3). The chipping on both sides of the scratched sample is definitely less vast than that observed in the case of the $(\mathrm{Ti}, \mathrm{Al}) \mathrm{N}$ coat on the same substrate. The only morphological defects of the hybrid coat are the drop-

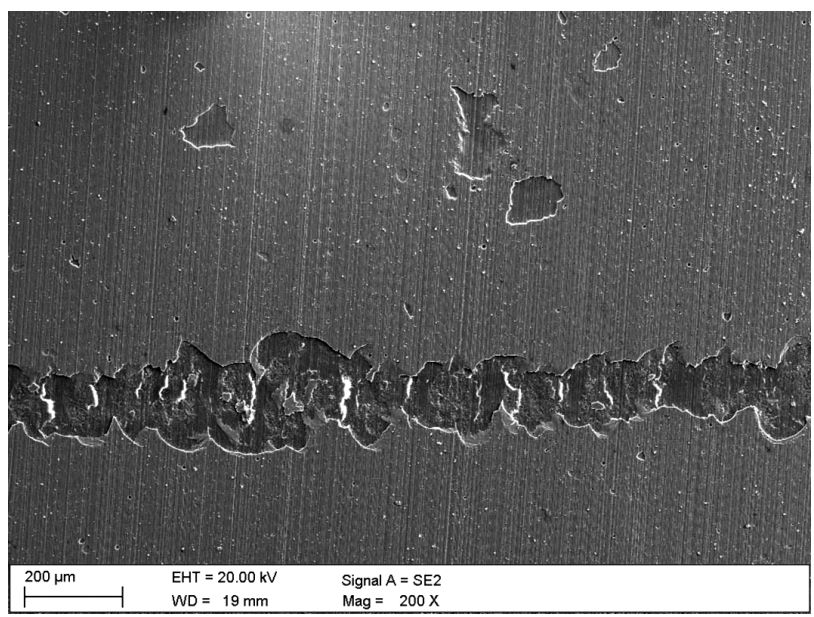

Figure 2: Characteristic failure obtained with the scratch test of the (TiAl)N coating deposited on the sialon-ceramic substrate

Slika 2: Značilna poškodba pri preizkusu z razenjem nanosa $(\mathrm{Ti}, \mathrm{Al}) \mathrm{N}$, nanešenega na podlagi iz sialonske keramike

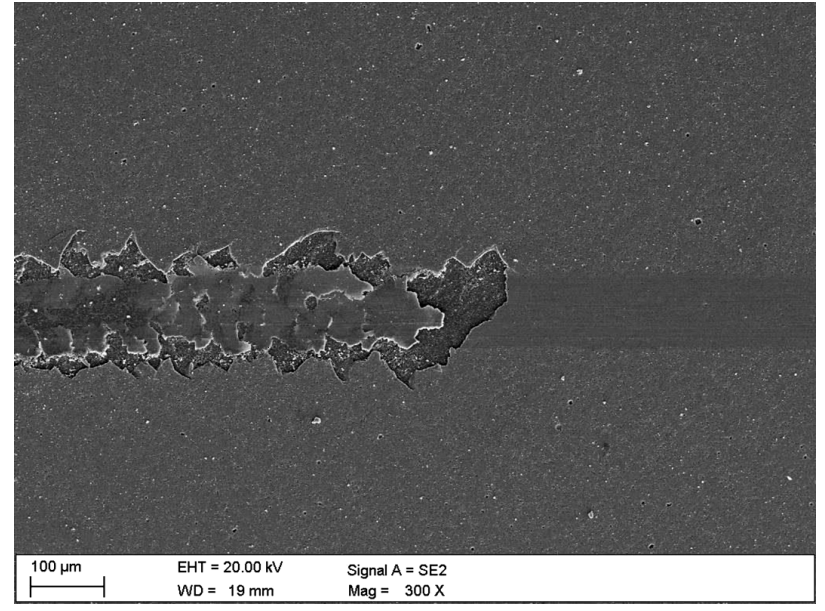

Figure 3: Characteristic failure obtained with the scratch test of the $\mathrm{ZnO} /(\mathrm{TiAl}) \mathrm{N}$ coating deposited on the sialon-ceramic substrate

Slika 3: Značilna poškodba pri preizkusu razenja $\mathrm{ZnO} /(\mathrm{Ti}, \mathrm{Al}) \mathrm{N}$ nanosa, nanešenega na podlago iz sialonske keramike

shaped microparticles, inseparably connected with the cathodic-arc evaporation process (Figure 4). In the case
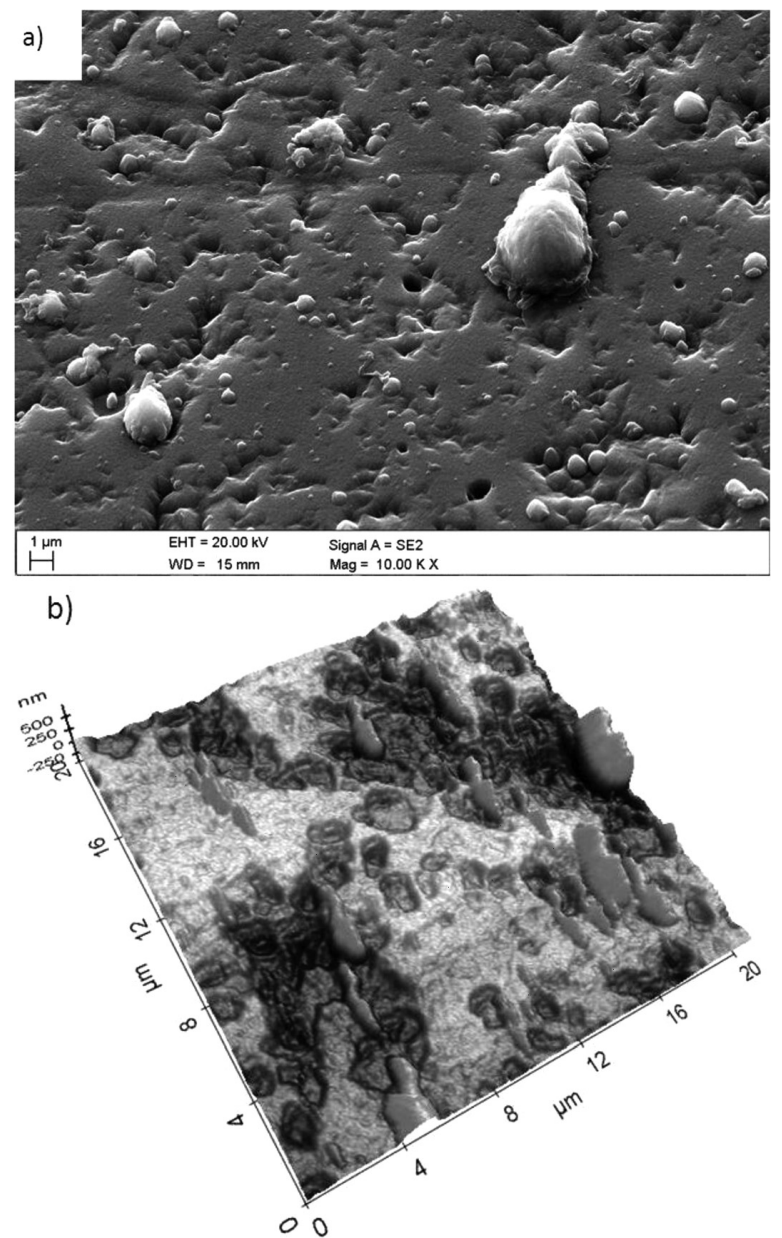

Figure 4: Surface topography of the $\mathrm{ZnO} /(\mathrm{Ti}, \mathrm{Al}) \mathrm{N}$ coating deposited onto the sialon-ceramic substrate: a) SEM, b) AFM

Slika 4: Topografija površine $\mathrm{ZnO} /(\mathrm{Ti}, \mathrm{Al}) \mathrm{N}$ nanosa, nanešenega na podlago iz sialonske keramike: a) SEM, b) AFM 


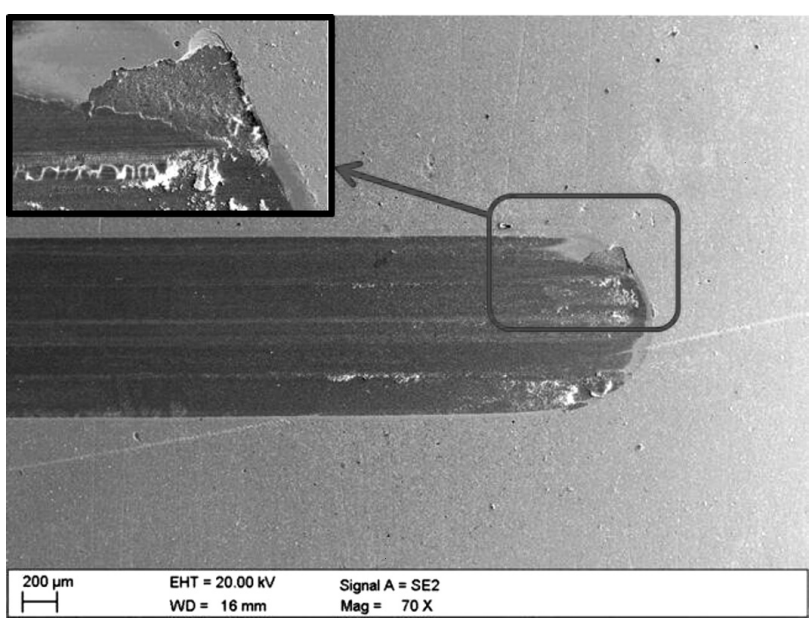

Figure 5: Trace of tribological damage on the surface of the (Ti,Al)N coat deposited on the sialon-ceramic substrate

Slika 5: Sled tribološke poškodbe na površini (Ti,Al)N nanosa, nanešenega na podlago iz sialonske keramike

of the coats on sintered-carbide substrates, friction is the dominant mechanism. In the case of the PVD coat on the sintered-carbide substrate, which is characterised by the highest adherence among the investigated samples, no abrasion deep down in the substrate was identified until the maximum load was reached during the scratch test. However, numerous cohesive cracks were identified after surpassing the critical load $L_{\mathrm{c}}$. In the $\mathrm{ZnO} /(\mathrm{Ti}, \mathrm{Al}) \mathrm{N}$ coat on the same substrate, we identified a uniform abrasion spreading down into the substrate after the critical load was exceeded.

With the tests on the abrasive-wear resistance of the coats deposited on sialon ceramics and on sintered carbides using the pin-on-plate method, we found that in almost all the cases where the coats were applied the coats were damaged down to the substrate zone (Figures 5 and 6). The dominant wear mechanism of the investigated coats was attrition. We also found that in some cases the damaged coat sticks onto the material of the counter specimen, which has a direct impact on the changing values of the friction coefficient. The research studies also confirm a positive impact of the $\mathrm{ZrO}$ layer on the attrition resistance as compared to the specimen without such a layer. At one end of the scratch, we observed a lot of damage to the coat deposited on the sialon substrate without the $\mathrm{ZrO}$ layer. The damage is of adhesive character - we can observe stratifications and cracks of the layer (Figure 5). And in the case of the coat deposited with the $\mathrm{ZrO}$ layer, the end of the scratch is uniformly grated without any adhesive damage (Figure 6).

\section{CONCLUSION}

Nowadays, the improvement of the wear resistance of cutting tools mainly involves surface machining, while the selection of the technology or coating material aims

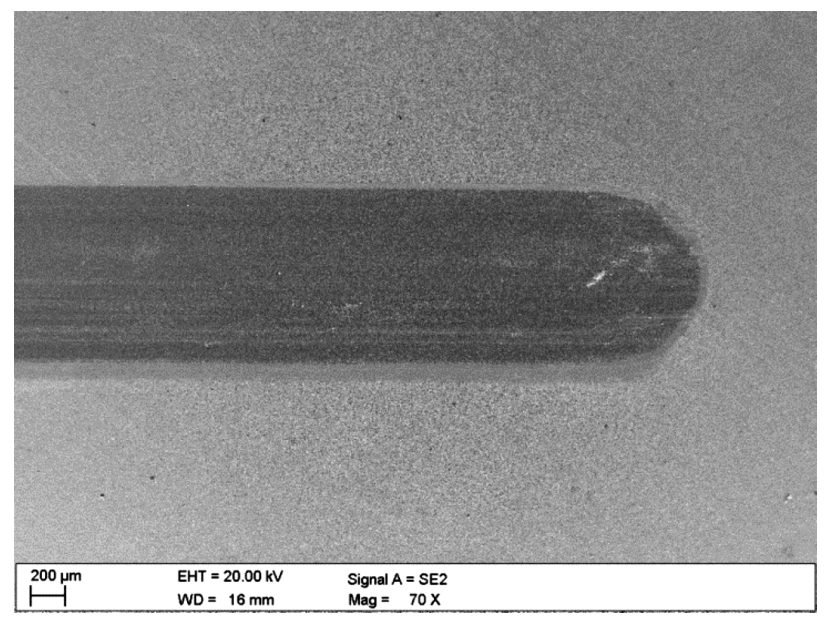

Figure 6: Trace of tribological damage on the surface of the $\mathrm{ZnO} /(\mathrm{Ti}, \mathrm{Al}) \mathrm{N}$ coat deposited on the sialon-ceramic substrate

Slika 6: Sled tribološke poškodbe na površini $\mathrm{ZnO} /(\mathrm{Ti}, \mathrm{Al}) \mathrm{N}$ nanosa, nanešenega na podlago iz sialonske keramike

at ensuring the proper resistance of a tool to dominant wear mechanisms. The operating properties of the coats resistant to the wear are the results of many components, primarily the microhardness, the grain size and the adherence to the substrate. Especially the last property is of key importance, and in view of the performed research studies $^{2}$, the grain size, the thickness and the microhardness of the obtained coats have smaller impacts than the adhesion on the durability of cutting tools since the changes in these properties have smaller impacts on service life.

The paper presents the results of research studies involving the application of an ALD layer to obtain a better adhesion of the PVD coat to the tool sialon-ceramic substrate or sintered-carbide substrate. We investigated the $(\mathrm{Ti}, \mathrm{Al}) \mathrm{N}$ coat deposited on both substrates, with the $\mathrm{ZnO}$ layer and without it. On the basis of the investigation studies, we can state that zinc oxide considerably improves the adherence of the PVD coat to the ceramic substrate, which was confirmed with scratch tests and observations of the damage made during the tests, using a scanning electron microscope. The critical load, being the adherence measure of the PVD coat on the ceramic substrate, increased due to the application of the adhesive layer by over $200 \%$. With respect to the investigated coats on sintered carbides, the adherence of the PVD coat to the ALD layer decreased as compared to the coat without ALD.

The improvement in the adherence of the PVD coat to the ceramic substrate is undaubtly connected with the possibility to polarize the substrate during the coating process involving the application of the $\mathrm{ZnO}$ layer. The results of the research studies are important since the deposition of ceramics in PVD processes is hindered due to the dielectric properties of ceramics. 


\section{Acknowledgements}

The publication was co-financed by the statutory grant of the Faculty of Mechanical Engineering of the Silesian University of Technology in 2015.

\section{REFERENCES}

${ }^{1}$ M. Sopicka-Lizera, M. Tańcula, T. Włodek, K. Rodak, M. Hüller, V. Kochnev, E. Fokina, K. MacKenzie, The effect of mechanical activation on the properties of $\beta$-sialon precursors, Journal of the European Ceramic Society, 28 (2008) 279-288, doi:10.1016/ j.jeurceramsoc.2007.05.003

${ }^{2}$ M. Staszuk, L.A. Dobrzański, T. Tański, W. Kwaśny, M. Musztyfaga-Staszuk, The effect of PVD and CVD coating structures on the durability of sintered cutting edges, Archives of Metallurgy and Materials, 59(1) (2014), 269-274, doi:10.2478/amm-2014-0044

${ }^{3}$ D. Janicki, High Power Diode Laser Cladding of Wear Resistant Metal Matrix Composite Coatings, Solid State Phenomena, Mechatronic Systems and Materials V, 199 (2013), 587-592, doi:10.4028/ www.scientific.net/SSP.199.587

${ }^{4}$ A. Lisiecki, Titanium Matrix Composite Ti/TiN Produced by Diode Laser Gas Nitriding, Metals, 5 (2015), 54-69, doi:10.3390/ met5010054

${ }^{5}$ A. Kurc-Lisiecka, W. Ozgowicz, W. Ratuszek, J. Kowalska, Analysis of Deformation Texture in AISI 304 Steel Sheets, Sol. St. Phenomena, 203-204 (2013), 105-110, doi:10.4028/www.scientific.net/ SSP.203-204.105

${ }^{6}$ T. Tański, Characteristics of Hard Coatings on AZ61 Magnesium Alloys, Strojniski Vestnik-Journal Of Mechanical Engineering, 59(3) (2013), 165-174, doi:10.5545/sv-jme.2012.522

${ }^{7}$ L.A. Dobrzański, D. Pakuła, Comparison of the structure and properties of the PVD and CVD coatings deposited on nitride tool ceramics, Journal of Materials Processing Technology, 164-165 (2005), 832-842, doi:10.1016/j.matprotec.2005.02.094.
${ }^{8}$ L.A. Dobrzański, L.W. Żukowska, J. Mikuła, K. Gołombek, D. Pakuła, M. Pancielejko, Structure and mechanical properties of gradient PVD coating, Journal of Materials Processing Technology, 201 (2008), 310-314, doi:10.1016/j.matprotec.2007.11.283

${ }^{9}$ K. Lukaszkowicz, A. Czyzniewski, W. Kwasny, M. Pancielejko, Structure and mechanical properties of PVD coatings deposited onto the X40CrMoV5-1 hot work tool steel substrate, Vacuum, 86 (2012), 1186-1194, doi:10.1016/j.vacuum.2011.10.031

${ }^{10}$ L. Żukowska, J. Mikuła, M. Staszuk, M. Musztyfaga-Staszuk, Structure And Properties Of PVD Coatings Deposited On Cermets, Archives of Metallurgy and Materials, 60(2) (2015), 727-733, doi:10.1515/amm-2015-0198

${ }^{11}$ B. Podgornik, V. Leskovšek, Wear mechanisms and surface engineering of forming tools, Mater. Tehnol., 49 (2015) 3, 313-324, doi:10.17222/mit.2015.005

${ }^{12}$ Z. Gronostajski, M. Kaszuba, M. Hawryluk, M. Marciniak, M. Zwierzchowski, A. Mazurkiewicz, J. Smolik, Durability of Hot Forging Tools by Applying Hybrid Layers, Metalurgija, 54 (2015) 4, $687-690$

${ }^{13}$ Guo-an Cheng, Dong-yan Han, Chang-lin Liang, Xiao-ling Wu, Rui-ting Zheng, Influence of residual stress on mechanical properties of TiAlN thin films, Surface \& Coatings Technology, 228 (2013), S328-S330, doi:10.1016/j.surfcoat.2012.05.108

${ }^{14}$ Hongfei Shang, Jian Li, Tianmin Shao, Mechanical properties and thermal stability of TiAlN/Ta multilayer film deposited by ion beam assisted deposition, Applied Surface Science, 310 (2014), 317-320, doi:10.1016/j.apsusc.2014.03.099

${ }^{15}$ Jian Zhang, Hui Yang, Qi-long Zhang, Shurong Dong, J.K. Luo, Forming-free resistive switching of tunable $\mathrm{ZnO}$ films grown by atomic layer deposition, Applied Surface Science, 282 (2013), 390-395, doi:10.1016/j.apsusc.2013.05.141

${ }^{16}$ V. Subramanian, T. Bakhishev, D. Redinger, S.K. Volkman, Solution processed zinc oxide transistors for low cost electronic applications, Journal of Display Technology, 5/12 (2009), 525-530, doi:10.1109/ JDT.2009.2029124 